\title{
The Dynamics of Social Network Structures and Contestation in the Collaborative Management of Lake Tempe in South Sulawesi
}

\author{
Muhammad Said ${ }^{1}$, Bevaola Kusumasari ${ }^{2}$, M. Baiquni ${ }^{3}$, \\ Subando Agus Margono ${ }^{4}$
}

\begin{abstract}
In managing common pool resources; ideally, it was carried out using a co-management approach that facilitated the cooperation, sharing of power, and responsibility among actors. However, this is quite difficult to achieve since each actor competes against each other's interests. Such cooperation and competition between actors will form a structure of social networks. This study aims to explain the dynamics of the formation of social network structures based on the cooperation and competition among actors in the management of Lake Tempe, a common pool resource crossing Wajo, Soppeng and Sidenreng Rappang Regencies in South Sulawesi Province. This is a qualitative study with explanatory case study approach, using two data collection techniques: participatory observation and in-depth interview with the government, fishermen, businessmen, and NGOs. This study found that the formation process of the social network structure in the management of Lake Tempe is a dynamic interaction among actors, i.e., cooperation in one side and competition on the other side, forming a social networking structure in two types: centrality and heterogeneity network. Network centrality occurs at the level of decision-making, the rules of play, and the allocation of resources, which is dominated by government actors, while heterogeneity network is dominated by communities that are still maintaining social capital such as kinship as well as knowledge and resources sharing. Brokerages, those who link the advantaged groups (local government and big-scale-fisherman/Pallawang) with the disadvantaged (small-scale-fisherman/ Pakkajalalla) do not exist in the management. Although the existence of brokerages is potential, they may also have a conflict of interest, since authorities and economic factors will be their target.
\end{abstract}

\section{Keywords:}

collaborative management; social network structure; contestation; common pool resources; natural resources management

\section{Introduction}

In managing common-owned natural resources that comprise the decision-making process and the allocation of natural resources, it is common that the contestation of interests will arise between actors. Contestation, as argued by Margono, et al. (2013) is the process of interaction between actors who claim each other for their interests in determining the

\footnotetext{
1 Department of Public Policy and Management, Faculty of Social and Political Sciences, Universitas Gadjah Mada.

${ }^{2}$ Corresponding Author. Department of Public Policy and Management, Faculty of Social and Political Sciences, Universitas Gadjah Mada.

Email: bevaola@ugm.ac.id

${ }^{3}$ Department of Regional Development Faculty of Geography, Universitas Gadjah Mada.

${ }^{4}$ Department of Public Policy and Management, Faculty of Social and Political Sciences, Universitas Gadjah Mada.
} 
management orientation of an item (specifically common goods) between social interests versus business interests, and social interests versus interests of authority, there is the struggle of each actor to represent his interests. Contestation of interests between actors occurs based on differences in knowledge, ideology, and expectations of each actor (Mitchell, 2010, p. 7). The actor referred here refers to parties that allow interest and influence, individuals, groups and organizations (such as government, private sector, non-governmental organizations, land users, and landowners) in a natural resource area. When the contestation of interests between actors is not well managed, it is feared that it will lead to a natural inability to fulfill various actors' requests (over carrying capacity). Hardin (1968) discusses it as the tragedy of the common, namely the natural resources tragedy because of continuous exploitation by various actors.

In accommodating interest contestations between actors, some experts promote collaborative management approaches based on social networks as a critique of the hierarchical and market structure approach that has existed in the natural resource management. Ostrom (1990) was a pioneer who initially criticized Hardin's (1968) writing, which only suggested mechanisms for managing common-owned natural resources (centralized-governance) through centralized-governance mechanisms and market mechanisms by private ownership (private-enterprise).

According to Ostrom et al. (1994), common pool resources are types of goods that the availability are limited, but many parties want to use them. Thus, management is no longer handled and dominated by a single actor or institution, but with a joint management approach (Ostrom, 1990; Berkes and Folke, 2000), co-management is used to facilitate collaboration between actors (Berkes, 2009; Sandström, and Rova, 2010; Carlsson and Sandström, 2008), and formulated in terms of the division of power and responsibility between state actors and users' local communities (Carlsson \& Berkes, 2005; Carlsson and Sandström, 2008). Dietz et al. (2003) prove and find the fact that through self-governing institutions analysis in managing natural resource, several community groups in the UK have successfully fought the threat of natural resource degradation in their country.

Based on the theory of shared management and general characteristics of natural resources that require cooperation, the distribution of power and responsibility among actors in management, Lake Tempe South Sulawesi, as one of the Mainland Common Water categories and common-owned natural resources, is ideally managed with a collaborative approach management based on social networks. However, the fact shows that social networks have not worked effectively to encourage collective action in integrating social, economic, and environmental interests. In fact, it is still dominated by the pursuit of economic interests of each actor to get the maximum economic benefits.

This can be seen from the management policies of 3 Regional Governments (Wajo, Sidrap, and Soppeng Regencies) which are still individually making Regional Regulations for the Management of Lake Tempe that is in their territory. Although several articles consider pro-environment management and maintain the social function of the lake, it still seems more dominant to be motivated to obtain locally generated revenue (PAD). Policy of The 3 Regencies Government to auction ex-ornament land shows the practice of commercialization and triggering social and economic polarization. At least, it can be seen from the relationship dynamics and ties that arise between auction-winning fishermen (Pallawang) who use harvesters and fishermen who use mobile fishing gear (Pakkajalalla). The auction winner fisherman (Pallawang) seeks to extract the natural resources that are controlled as much as possible to gain 
profits by reason of issuing capital. While small fishermen (Pakkajalalla) feel increasingly pressured because they have increasingly narrow fishing areas, so they make complaints by using prohibited fishing gear (illegal fishing) and carrying out disturbances to the auction winner's land for survival purposes. At the same time, the local government should be present with its authority to enforce regulations, but in reality, it seems helpless to control illegal fishing, which is increasingly prevalent.

This research focuses on the dynamics of the formation of social network structures behind the contestation of interests between these actors in the management of Lake Tempe. This research focused on the pattern and content of the relationships between actors expressed through the patterns of relations of interests, knowledge, and authority of each actor in the management of Lake Tempe. The theory used in this study to explain the pattern of relations of interests, knowledge, and power between actors is the theory of social networks. In this context, this study follows Granovetter (in Ritzer and Goodman, 2010) who examines social networks from actions of relations between actors that occur at the level of macro and micro social structures. According to him, through relationships between actors, form structured and tended to be stratified bonds, where one particular component depends on other components (interdependence), so that the relationship was based on the idea that each actor (individual or collectivity) has different access to valuable resources (wealth, power, information).

One of the basic principles of social networking is to enable symmetrical and asymmetrical relationships to occur between actors in social action. Symmetrical relationships occur when actors supply different resources based on their level and intensity. Asymmetric relationships occur when there are elements in a wider network system with limited resources distributed unevenly or lame. Uneven and unequal distribution of limited resources forms an imbalanced network structure that forces actors to cooperate and compete (structural coercion) in fighting over a natural resource. Some individuals and groups will join to get limited resources by collaborating, while some individuals or groups will compete for resources (Ritzer and Goodman, 2010)

Recent research on social networks in managing natural resources has largely explored the role of social networks, in terms of collaboration between actors (Bodin and Ernston, 2006; Bodin and Crona, 2009, Lauber, et al. 2008; Crona and Bodin, 2006; Prell, et al. 2009; Yamaki; 2014). For example, Bodin and Ernston (2006) have concluded that the existence of social networks is a general dominator, and it is important to facilitate collaboration between different actors and stakeholders in natural resource management. Meanwhile, studies of social networks are rarely found in terms of competition or asymmetric relationships between actors. For this reason, this paper focuses on elaborating the dynamics of the emergence of asymmetric social network structures in the management of Lake Tempe.

Previous studies have established two distinctive forms of network structures that affect the performance of natural resource management; namely, network closures and network heterogeneity (Yamaki, 2014, Bodin and Ernston, 2006, Bodin and Crona, 2009; Sandström \& Carlsson 2008; Sandström \& Rova 2010a, 2010b). First, the closeness or network closure, which is evaluated by the level of connectedness, associated with social ties or solidarity between actors in clicks or groups (bonding). Network closure can be seen in two forms based on the level and intensity of the actor's relationship, namely (1) density network, where actors are directly connected to each other; and (2) centralized networks, where most actors are directly connected with central actors and other actors are indirectly connected 
through central actors.

Second, network heterogeneity is related to structural holes; namely, connections between various sub-groups that are structurally separate, such as in an organization or a certain sector directed towards bridging actors (individuals or groups) that have separated (Burt, 2001). This study explains the dynamics of the formation of 3 typologies of the structure of social networks; namely, the network of closeness, centralized networks and structural holes in the case of Lake Tempe, South Sulawesi.

\section{Method}

This research was carried out in Lake Tempe, South Sulawesi Province, which traversed three Regencies, namely Wajo Regency, Soppeng and Sidenreng Rappang covering 7 Sub Regencies and 26 villages/ region which bordered directly. Lake Tempe was chosen as the location of the study because at this location; there was a social network between actors in the management of Lake Tempe. Each actor interacts (cooperating and competing) representing their respective interests in the use of natural resources at Lake Tempe (Figure 1 Map of Research Locations).

This research is qualitative research with an explanatory case study approach following the opinion of Yin (2006) to answer "how" or "why" research questions directed to a series of contemporary events, where the researchers only have little chance or no opportunity to exercise control against the event. This study aims to answer the question "how" the dynamics of the formation of the social network structure behind the contestation of interests between actors in the event of natural resource management at Lake Tempe, South Sulawesi.

The data collection techniques in this study were, first, in-depth interviews with seven people from the Government, five big

Figure 1.

Map of Research Locations

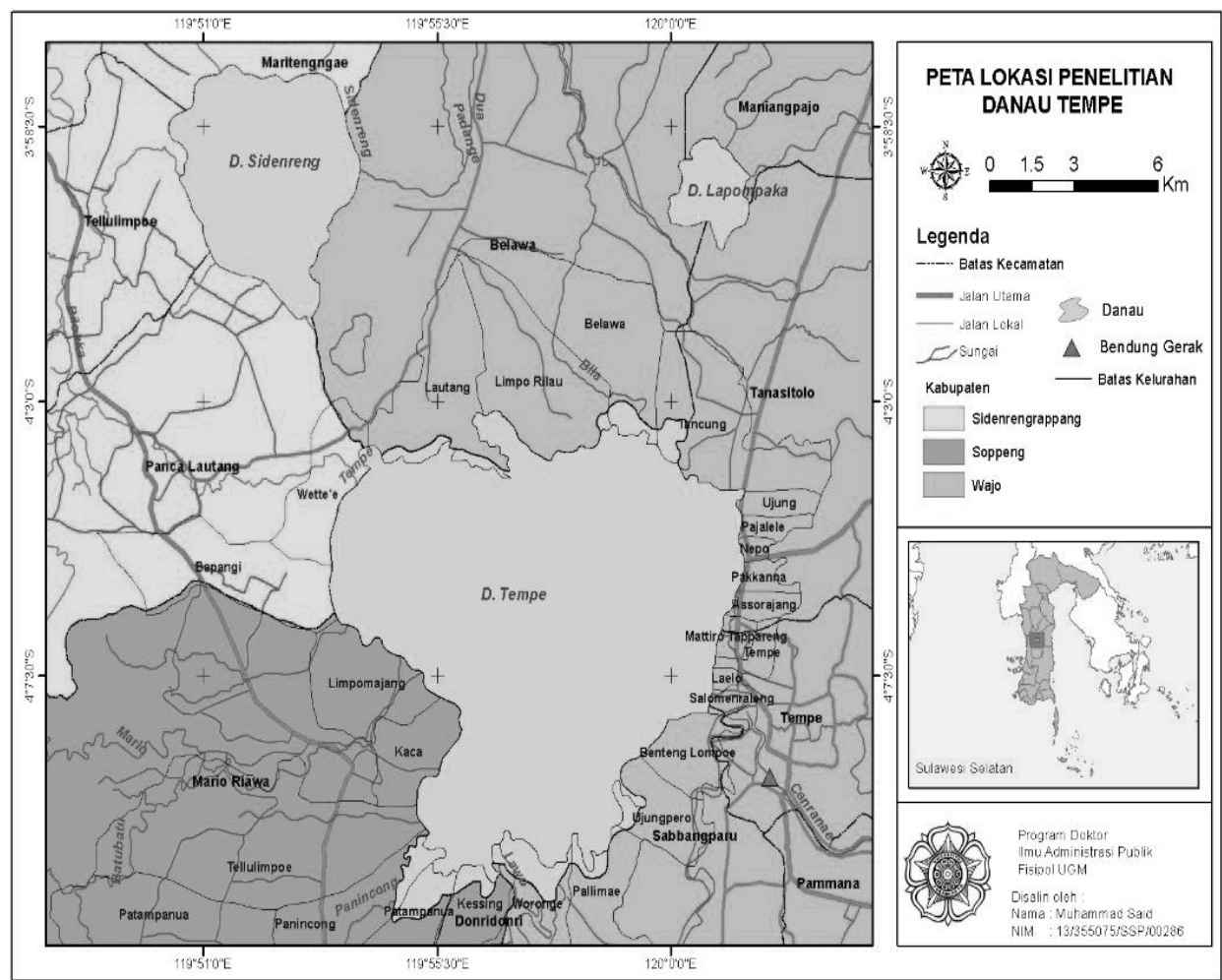

Source: adopted from KLH, 2014. 
fishermen, 30 small fishermen, two traders, and 2 NGOs. Determination of the informant was carried out using the snowball technique, which is extracting data and information to informants who know the context of the study through indepth interviews from one informant to other informants and so on until the researcher does not find new data and information (Hamidi, 2005, p. 75). Second, the data collection techniques used are observations involved in following Baiquni (2007) to see directly and deeply the social processes and social network structures that take place in the research area, so that it achieved a general description of the condition of the research area and actual issues in the community related to the theme of this research. Observations were carried out in an engaging manner, specifically to observe who the actors that involved in social networks are and how the processes and mechanisms for the formation of social network structures behind the interactions between actors in the management of Lake Tempe.

\section{Result and Discussion \\ Dynamics of Actor Relations and Contestation of Interest}

Lake Tempe is a lake of flood plain in the Walanae River and Cenranae Rivers in South Sulawesi. The Lake Tempe Basin consists of terraces and floodplains. The terrain is generally flat in shape, located a few meters from the flood plain, but the boundary between the two plains is not firm. During the dry season there are three lakes; namely, Lake Tempe, Lake Sidenreng and Lake Buaya, which are separated and only connected with naturally formed waterways. During the rainy season, all the three lakes are united into a single pool of lake, and by the local community are called the flood. The area of Lake Tempe during the rainy season of March - July is approximately 28,000 ha with water elevations from 6.0 to $7.0 \mathrm{~m}$ above the sea level and 43,000 ha at elevations from 7.0 to $9.0 \mathrm{~m}$ above the sea level. In the dry season, it will reach water elevations at around 0, 50 2, $0 \mathrm{~m}$ above the sea level or an average of 1.25 $\mathrm{m}$ above the sea level only reaches 10,000 ha (KLH, 2012; KLH, 2014; KLH, 2006).

The management case of Lake Tempe has become an arena of contestation of interests between actors when there is value manipulation between Lake Tempe as a common pool resource (or shared property) shifting into state or private property whose management practices are controlled by an individual or group. One of the basic principles of common pool resource is that its resources are limited, but many actors or stakeholders are willing to claim and utilize these resources.

If a fishery land is controlled by one individual or a group, it will automatically exclude other individuals or groups to utilize the fishery land. At this point, emerged actors who dominate dominated the management practices of the Lake Tempe. Social networks work as a mechanism of relations and ties between actors (individuals, groups or organizations) that take place in the middle of actors who pursue each other's desires. The dynamics of the relationships and ties between these actors form the structure of the social networks.

As is known, the management of Lake Tempe is very complex, full of uncertainty and the potential for conflict of interest. It is complex because it relates to one spatially integrated area, but is limited by the administrative and political boundaries of 3 Regencies (Wajo, Soppeng, and Sidrap) as freshwater fisheries cultivation areas in three Regencies (Maros, Enrekang and Bone) as upstream and downstream of the Watershed (DAS). Full of uncertainty is because natural resources are greatly affected by climate change and the socio-cultural conditions of the society that are constantly changing. Potential conflicts of interest occur because of the diversity of actors and interests that play as many have previously described the existence of mutual claims, differences in values, knowledge, and 
degrees of power among the actors involved.

Although the management of Lake Tempe is very complex, decision-making was found to be still done individually by each Regency. This can be seen from the official decision of each by issuing a Regional Regulation or Regents of the Regent, namely:

1. For Wajo Regency with Regional Regulation No.4 of 2012 concerning Management of Fisheries Resources in Wajo Regency;

2. For Soppeng Regency with Regent Regulation No.13/Perbub/VI/2012 concerning Procedures for Common Water Management and Tappareng Salae, and

3. For Sidenreng Rappang Regency with Regional Regulation No.4 of 2010 concerning Management of General Fisheries Resources in the Sidenreng Rappang Regency.

Based on the Regional Regulations document and 3 of the Regencies, it was found that the similarities in the basis of the government's thinking in taking the management decisions of Lake Tempe, include (1) agreement on administrative boundaries marked by concrete stakes; (2) fishing procedures; (3) fishing gear requirements; and (4) conservation area.

At the very least, the rationale for decisionmaking in managing Lake Tempe can be found in the narrative that currently Lake Tempe is over fishing; many fishing gears do not fit the type and their size. In accordance with the Regional Regulation 3 of the Regencies, the net is set to be above $5 \mathrm{~cm}, 7 \mathrm{~cm}$ and $9 \mathrm{~cm}$ and a maximum length of 500 meters, so as not to catch small fish. However, the fact is that there are those who use under $5 \mathrm{~cm}$ and their length exceeds 500 meters. In addition, there are also fishermen who use prohibited fishing gear, such as storage storm, tiger trawlers, and trawlers and Cantarng (Tongkang).

In addition, the Regional Regulation 3 of the Regencies underlies the auction mechanism of ex-ornamental land, which is known locally as Pallawang belonging to the Regional Government with the aim of increasing Regional Original Revenue. In Soppeng Regency, there are 12 ex-ornaments and Tappareng Salae land points. In Wajo Regency, there are 27 Pallawang locations spread in 4 Districts and Sidenreng Rappang Regency, there are 2 locations in Panca Lautan District.

Interestingly, because there is also a land owned by the Regional Government, there is also a private location, which, if traced, the owner or master (Mangongko) of these lands is the descendant of Datu (King) who once ruled the area or former District Head and Sub-district head who had ruled or ruled in the region. There are also those who are still controlled by the sub-district head who rules in a region, so he has the right to manage for the benefit of the government. For example, the Belle Barue location located in Woronge Village, Sabbangparu District, Wajo Regency which borders Soppeng Regency, which is about 100 $\mathrm{Ha}$ in size. In addition, there has also been a changed hand to ordinary citizens because of the process of purchasing or mastering the process based on family claims (Ongko) for generations. The rest is free access (open access) by the captured fishermen (Pakkajalalla) whose area is wider than the government property and private property. Free land access can be transformed into private or group control when individuals or groups install permanent fishing gear, such as Bungka Toddo, which is claimed by one family from generation to generation.

Based on the management mechanism, it is found three ownership regimes; namely, the local government property, the private property, and the common property free access. Actually, this ownership regime is more appropriately referred to as Ongko as the name and term known by the residents in Lake Tempe; namely, land tenure claims by actors (individuals or groups) for a certain time and certain water depth conditions.

In Wajo Regency, the period of the tenure 
of the auction is two years but is controlled only from 1st of May - 31st of December every year. In Soppeng Regency, the tenure in the auction is one year but is controlled from 1st of July - 31st of December, outside that period, the land changes to open access, meaning that it can be accessed by the captured fishermen (Pakkajalalla). In Sidenreng Rappang Regency, the tenure auction was two years and was held for two years without any lags, such as in Soppeng Regency and Wajo Regency.

Land tenure by the auction winner (Pallawang) is regulated depending on the conditions of certain water depths. Although, in the auction tenure period and within the stipulated time to be mastered; however, when the water depth in the lake is above 1.45 meters, then the land may be accessed or become a fishing area that is free for the captured fishermen (Pakkajalalla). Exceptions occur in Sidenreng Rappang Regency, where land acquisition by auction winners is held for two years permanently without any time with certain water depth conditions.

With the complex management dynamics, on the one hand, the local government gives access rights to the auction winner (Pallawang) to be controlled for a certain period of time, but on the other hand also gives concessions to the capture fisherman (Pakkajalalla) to access through the time and condition of the water's depth. So, at the community level, there are mutual claims that have implications for the reality of relations between actors versus the legal rights and control of each actor.

Based on the observations involved, the author found at least two types of rules that apply at the Lake Tempe; namely, the formal rules and the informal rules. Both formal rules and informal rules are constructed to regulate, control, and manage the actors in the management of Lake Tempe. The formal rules are arranged formally and in writing from the government which is vertical. It is called vertical because the rule came from the government, which was applied, to residents in Lake Tempe. The sanction mechanism was stipulated in writing and officially carried out or enforced by the government officials, such as the Joint Lake Tempe Control Team (Police, Community Police Officer, Common Administration Officer, and Fisheries Main Station) to everyone who violates these rules.

Meanwhile, informal rules are rules that are regulated and agreed upon by citizens from generation to generation, relying on oral traditions, local customs, and horizontal characteristics. The sanctions mechanism is a social sanction that was regulated and agreed upon which is carried out by traditional elders called Macoa Tappareng (lake elders from men) and Pabbijagae (spokespersons and executors of ritual events from women).

From the two types of rules of the game that apply at Lake Tempe, there are differences in claims (contestation) of interests between actors in interpreting these rules, the level of compliance and submission of citizens and the implementation of existing sanctions mechanisms. For the Regional Government the formal rules of the game are fair enough to regulate the fishermen who use Lake Tempe; moreover, the process of determining it at the beginning of the preparation of Regional Regulations was carried out in a participatory manner involving NGOs, Universities and local Fishermen. However, for the captured fishermen (Pakkajalalla), the rules for playing with this open auction system only benefited a few people who had money to pay rent and actually violated the customary rules of permanently installing fishing gear (Mattang Poli ').

Rules that can be accessed when the water is above 1.45 meters or "assala" "assala" weddingngi mopi nola lopi yase'na belle'e makkajai campongnge" (as long as the boat can still pass above the attached splint catching gear can be accessed. This was based on the small fisherman; it is almost impossible to enforce because 
the auction winner (Pallawang) is "tricky" by installing a connecting device over the splint, so that no boat can pass. Likewise, with rules that allow access by anyone when the water recedes to become Palawija farming area, which it is almost impossible to implement, because the auction winner (Pallawang) always argues that they are experiencing a loss.

For big fishermen (winner of the auction/ Pallawang), the rules that stipulate regular management time; namely, July - December for Soppeng Regency and May - December for Wajo Regency cause Pallawang fishermen to often suffer losses due to climate factors that often change. According to Pallawang fishermen, the rules should follow climate change because the capture fisheries system in Lake Tempe is actually based on tides.

Based on the results of several interviews, it was found that even when the auction rules were open, there were several factors. Thus, not all fishermen wanted and could take part in the auction, including the flow of information spread from the committee to all fishermen, fishermen's proximity to the committee or local government, actor knowledge about the auction mechanism, experience participating in the auction. Therefore, generally, those who win an auction are village elites who have economic capital, have strong information on correlations with local government officials. While the captured fishermen (Pakkajalalla), even when they knew that the auction was open, anyone could follow it, but they did not know or did not want to know how to participate in the auction process; besides, lack of capital was the main reason. The only thing they can do is just to watch the auction at the Sub-district head's Office and to wait for who wins one particular location. Captured fishermen (Pakkajalalla) are important to know who the auction winner is because it will later affect the workforce on the land. It can be seen who won the auction from year to year; it will appear that the name often appears and recurs as the winner.

The dynamics of other actor relations are how actors interpret formal rules, informal rules, and the mechanism of sanctions from each type of rule. As an example in the formal rules, it is prohibited to use fish stunner, tiger trawlers (Jabba 'Trawls), trawls of (Jabba' Bessi), net Tongkang and Bungka Toddo ' which size should only be 125 meters' x 125 meters and Lanra' (nets) that must be above $5 \mathrm{~cm}$ and a maximum length of 500 meters. However, in the field, there are many violations of fishing (illegal fishing), especially the use of prohibited fishing gear, a distance of Bungka Toddo' and the size of the net that should be used.

From the results of the observations and interviews, it was found that there was a tendency for the fishermen to violate the formal rules due to economic urgency or the desire of the fishermen to get more catches. In addition, Lake Tempe fish stocks are increasingly limited along with the many fishermen who depend on this lake. The emergence of modern fishing gear such as Tongkang and Jabba Bessi 'in the early 2000s replaced traditional tools such as Bubu', spear, Konde,' Julu' and Salekko 'and increased illegal fishing is known to contribute to increasing fisherman competition in getting results fish at the Lake Tempe.

Responding to the rampant illegal fishing, the regional governments in the 3 Regencies initiated the establishment of a Community Monitoring Group (Pokmaswas) in their area. This Pokmaswas serves to supervise and direct control of illegal fishing activities. The core management (Chairperson, Secretary, and Treasurer) is taken from the fishermen elements plus a joint team of fishermen elements, Head of Fisheries Main Station, Fisheries Extension, commander of the army administrative, head of district police, police officer, Prosecutors, and village chief/village. In its journey, the Pokmaswas was not functioning properly. Fishermen can "play cat and mouse" with patrol officers, if Wajo officers hunt fishermen 
in Wajo, fishermen can run to Soppeng, which is no longer their territory. Even when found, the Chairperson of the Pokmaswas himself claims to use Jabba Bessi trawl, while showing the tool to the author at his home. According to him, this has to be used, if you don't use it, what do you want to eat? As it's hard to find fish. In addition, he also highlighted the Pallawang system, which was dominated by rich people and close to the local government officials.

In contrast to the formal rules, it seems that the informal rules are still abstinence to break by citizens. It is known that there are still many residents who abstain from fishing in sacred places, bring two fishing gear at once, catch fish on Friday nights and bring their wives to join in catching fish. After being asked further, commonly, they stated that they were afraid of getting social sanctions in the form of fines (Idosa). In addition, they also believe this action gives the opportunity to fish to rest and breed, so that later on the day, the income will be abundant. They also believe that when someone violates this custom, it will be discovered during the Maccera Tappareng event, where customary violators will be caught when Macoa Tappareng and Pabbijagae are possessed. At the time of the confusion, the fishermen's violations will be revealed, the time is too late, there is a flag there, wrong intention, why should the goat, it should be buffalo, because this year's results only get this much but why only cattle, all kinds of things, but that is surprising. However, these past years have always been buffaloes; I have heard that fewer people are possessed.

Although, the informal rules persist until now; however, according to some fishermen and community leaders that the informal rules have begun to erode, for example, the Maccera Tappareng event has been challenged by the Islamic groups, especially Muhammadiyah in Wajo because it was considered Mappadua (Godly or Shirk). In addition, there have been several changes in orientation. It used to be a ritual event, in which full of meaning and symbols began the work of fishermen and read natural signs, whether the work or income of fishermen in this season would be abundant or bad. - It is therefore always carried out at the beginning of the tide as the meaning of picking up water (Maddupa Uwwai). - Now, it is turned into a "local government protocol" event with the name "Tempe Lake Festival" followed by a boat race, not just the changing times, which usually adjust 17 August event, but also its orientation is more towards the tourism destination, and the executor of the program has also changed. Formerly, the dominants were traditional leaders and figures of fishing communities led by Macoa Tappareng, but now, more from the Department of Tourism and Culture in collaboration with the Fisheries Service.

Based on the results of these studies, it can be concluded that in determining the formal and informal regulatory framework, there are actors who have the most role and dominance. In the formal rules, it was found that the most important and dominating actors were state actors who were supported by the local business actors who obtained economic benefits from the regulation. The state actors have a high level of influence, and a high level of importance in determining the rules of the game and sanctions, but do not get strong legitimacy at the level of the community. While the informal rules that have the most role and dominant are traditional leaders (Macoa Tappareng) with a high level of importance and influence and gain the legitimacy and compliance of the local fishermen compared to their compliance with formal rules. In terms of urgency, both formal and informal rules are equally important to balance the social, economic, and environmental aspects of natural resource management at Lake Tempe.

Although, there was no manifest conflict between Pallawang and Pakkajalalla because of the kinship ties between them and the existence 
of customary rules and mutual dependence on the relations of workers and capital owners, as it gave rise to a subtle elite capture. Quoting Das Gupta, et al., 2004: 28 in Setiadi, et al. (2016) that elite capture is "serious power imbalances ... the poor are heavily dependent on vertical links with local elites. [therefore] it is difficult to form the horizontal associations necessary for organizing collective action for the common good." When collective action is co-opted by the interests of some of the elites, the elite will take advantage of it (Bardhan and Mookherjee, 2000 in Setiadi, et al. 2016). Elite capture is increasingly unstoppable when socio-cultural models of social relations prioritize harmony; avoid conflict, as well as there is no check and balance (Setiadi et al., 2016).

\section{The Reality of the Structure of the Formed Social Network}

The dynamics of relations between actors and the contestation of interests that take place between state actors, big fishermen (local entrepreneurs) and small fishermen as described earlier reflect a relationship of interests and asymmetrical power relations. This is in accordance with the basic principle of social networks that when an asymmetrical relationship occurs, where the resources among actors were distributed unevenly, it equitably forms an unequal social network structure. Bodin and Ernston (2006) emphasize that the typology of the structure of social networks was influenced by the dynamics of relationships and ties between actors that can be seen from the characteristics of the pattern and content of the relationship. The pattern and content of relationships is a process of social interaction that works, which can be detected through the process of transferring knowledge, sharing information, and building consensus among actors from relationships of interests and power.

From the dynamics of relations between actors in the management of Lake Tempe; at least, it was found three typologies of social network structures were formed, namely [1] network closeness or cohesiveness; [2] network centrality; and [3] network heterogeneity or Burt (2001) called as structural holes.

First, the density network, which is a network formed because the actors are directly connected. In the case of the management of Lake Tempe, there were clicks or groups of users of freshwater fisheries. In the open access area, there was a close relationship between small fishermen. Small fishermen are fishermen who use fishing gear that was installed to move in no more than one day or 1 night. Because the fishing gear moved around and was not installed permanently, they were referred to as Pakkajalalla (migratory fishermen) to find fish where according to knowledge, experience, and information from fellow fishermen it was possible to catch more fish. At the level of Pakkajalalla, it was found to click according to the fishing gear used and the time chosen to start searching for the fish. For example, Pakkajalalla uses a net fishing gear (Lanra) and both depart in the morning and returns home in the afternoon, they call it Pallanra Esso (fisherman nets during the day); a kind of fishing club that uses nets (Lanra) on daytime. The same thing happens to fishermen who use nets that leave in the afternoon and go home in the morning; they call themselves Pallanra Wenni (fishermen nets at night). Generally, they have a very strong network of closeness, both of those who meet on the lake from 3 regencies and (moreover) from the same village. They build a high level of kinship and cooperation in solving the problems faced. They also shared knowledge and access to resources at Lake Tempe, sharing of knowledge about places to catch more fish.

Pada Lao Te Pada Upe' (the same goes not the same fortune) is a phrase often spoken from a capture fisherman in the waters of Lake Tempe when they saw other fishermen catching more fish. Although departing at the 
same time, the same type of boat and fishing gear are the same, but sometimes the results (which are interpreted as fortune) are not the same. Different fortune does not make fishermen jealous, protest and fight. But on the other hand, fishermen can protest with various expressions: damaging fishing gear, taking fish and terrorizing other fishermen when there are fishermen or other parties who violate norms, control (Mangongko) a land and government policies that hinder and/or reduce their fortune, which according to them has become a right that has been mutually agreed upon.

When catches using nets start to decline, they usually give information to each other about what fishing gear can catch more fish. From this mutual information, this was the beginning of the emergence of banned modern fishing gear, such as iron wire nets (Jabba 'Bessi'), tiger trawlers, Tongkang (bambooshaped parabola made of bamboo or iron) and storage storms.

The closeness network can also be seen from the employer-labor relationship (patron-client) between small fishermen and local entrepreneurs (big fishermen) who win the auction of the local government-owned land with a profit-sharing system. Small fishers usually work in a double profession, one day, they become laborers during the harvest season in Pallawang and on the other day, they keep looking for fish in free areas as usual. Between the employer and the workers, there is intertwined with mutual trust. As an employer, it must be ensured that the profit sharing is according to the agreement, as a worker must ensure not to cheat and steal fish (Maceko-Ceko). In addition, close networks can also be seen from the relations between fellow local entrepreneurs (big fishermen). They usually give information to each other about auction times and requirements with the lowest number of bids. When the auction was held, they usually managed each other's strategies, for example, H. Sau wanted to win a location, so they told their competitor, $\mathrm{H}$. Ruse 'that had to put lower bids below him, even when the difference was only 100,000 IDR vice versa. After being explored further, the common auction winner usually has a kinship and family network.

A network of closeness can also be seen between local government actors as auction implementers and local entrepreneurs. In some cases, the auction winner is the Bupati (officer in charge of regency) candidate's success team and legislative members; so that later, the auction mechanism will become a medium of exchange.

This density is actually a bonding social capital between fishermen which can contribute to the strengthening trust between individuals and groups, thus increasing the possibility of social control over resource use (Granovetter, 1985; Coleman et al., 2008; Pretty and Ward 2001 in Bodin and Ernston (2006)). However, the closeness of the network has the potential to further erode the preservation of Lake Tempe's natural resources when there is a homogenization of experience and knowledge. In order to obtain abundant fish locations and innovation in fishing equipment that is not environmentally friendly.

Second, network centrality occurs at the level of determining regulations, implementing rules for playing management, and allocating land dominated by state actors, in this case, the local governments in 3 Regencies. The position of the state occupies the center of the structure that was supported and utilized by the local entrepreneurs to influence the management decisions of Lake Tempe so that the decisions remain stable and provide benefits for themselves and their groups. State actors and local entrepreneurs are at the top of the centrality structure, while small fishermen are on the periphery network structure. This is because of this centrality network, the state benefits as a source of authority and profit for large fishermen (comprador) as a source 
of economic income. Although, according to Bodin and Ernston (2006), centrality networks have advantages and disadvantages. On the one hand, it can create effective coordination of the actors and users of resources at the beginning of the decision-making process. However, on the other hand, the disadvantages are greater because it can lead to increasingly centralized decision making and reduce access to marginalized individual actors for various sources of information according to their aspirations and interests.

Third, the structural hole referred to in this study is the connection between various sub-groups that were structurally separated, such as in an organization or a particular sector. In the case of Lake Tempe management, it was found that at least four groups of actors that had the potential to become separate clicks; namely, state actors (3 regional governments), local entrepreneurs (big fishermen), small fishermen, and NGOs. The four categories of actors were ideally placed as key players who are expected to build cooperation, share power, responsibility, and collective action to solve social, economic, and environmental degradation problems in the core region of Lake Tempe Region as an integrated spatial unit. The potential fact has already formed with the fact that big fishermen (local entrepreneurs) have close relations between large fishermen across the Regency. Small fishermen have relationships and ties between small fishermen across Regencies. NGOs have been informed about the establishment of the Tempe Lake Rescue Forum across the Regency. Therefore, groups of fishermen fit their categories and NGOs have the potential to become one large group and have no problems in collaborating across Regions. It's just that in the Regional Government actors found a structural hole between the 3 Regencies with no legal and law protection together to regulate the management of Lake Tempe.

The structural hole at the fishermen level actually occurs between large groups of fishermen and small groups of fishermen in terms of inequality of resources (interests, power, and economy) in accessing and controlling the Lake Tempe. Small fishers are a group that is cut off from access, which is always losing in competition for the benefits and benefits of natural resources at Lake Tempe, even when this structural hole is social capital that can be activated to bridge separate actors (individuals or groups) in facilitating collective management action.

For this reason, Bodin and Ernston (2006) proposed a broker as an actor who embodies "social bridging" from the community to bridge broken and losing groups. According to him, the advantage of being a broker is that it can access a lot of information from specific groups and then replicate it in different groups that allow brokers to synthesize knowledge of natural resources extensively. In addition, through structural positions, brokers learn about the inner life of many different groups and therefore, through their position, benefit from knowing which groups or individuals were connected or not connected, and how to connect them, (Burt 2001 in Bodin and Ernston 2006).

However, the broker who is expected to connect between groups that get a lot of profits (Pallawang) and the losing group (Pakkajalalla) does not appear on Lake Tempe. Although, the potential exists as in H. Sau (Soppeng), $\mathrm{H}$. Karding (Wajo), Usman Pangade (Wajo) and La Bure (Sidrap), "they are people who are close to the local government, and they are very close to the citizens and respected in their area. They also have an extensive network in the Lake Tempe Region and at traditional markets and places of sale for fish." However, they are also trapped to pursue economic interests as much as possible as auction winners (local entrepreneurs) and often become a successful team of candidates and regional heads in the election and regional elections which make 
them suffer from personal conflicts of interest.

The NGOs Lake Tempe Rescue Forum also has the potential to become a broker but has limited strategies for organizing small fishermen and limited data based on the livelihood conditions of small fishermen. It seems that NGOs were trapped using technical data from the local government to support the decision to pass the management and permissive auction mechanism for several lake revitalization projects.

\section{Conclusion}

Based on the results of this study, it can be concluded that: First, the relationship between actors and contestation of interests that arise in the management of Lake Tempe (determination of rules, enforcement of rules and complaints of actors) show an asymmetrical relationship of interests and power. An asymmetrical relationship took place because the resources of each actor were distributed unevenly. State actors and local entrepreneurs (big fishermen) have a strong network and a high degree of influence in determining the rules and allocation of Lake Tempe resources. While small fishing actors have a high level of importance but a weak level of influence, the implication is that small fishermen complain about formal rules with the widespread use of illegal fishing and disturbances to the area of land that is auctioned by the local government. In this context, the legitimacy of the state is considered weak because it is unable to control illegal fishing. As a result, natural resource management at Lake Tempe continues to perpetuate "the tragedy of the common."

Second, the structure of social networks that were formed from the asymmetrical relations of interests and power are networks of closeness, centralized networks, and structural hole: First, the network of closeness occurs between small fishermen at the community or community level with high kinship and cooperation in solving problems at the community level. There is the sharing of knowledge and access to resources at Lake Tempe. There is the sharing of knowledge about fishing gear that can produce more fish. Closeness also occurs between groups of large fishermen and small fishermen, so a patron-client relationship is formed. The network of closeness also occurs between big fishermen and state actors (local government) in maintaining the commercialization of ex ornament lands.

Second, network centrality occurs at the level of determining the management and distribution rules of land control, which are dominated by state actors or local governments in each region. The position of the state, which occupies the center of the structure, is supported and utilized by local entrepreneurs to influence the management decisions of Lake Tempe so that the decision remains stable and provides benefits for themselves and/or their groups that trigger elite capture on one side and the removal of small fishermen subtly on the other side. State actors and local entrepreneurs are at the top of the centrality structure, while small fishermen are on the periphery network structure.

Third, a structural hole appears in the form of clicks or groups, namely clicking the local government of each Regency, clicking on local entrepreneurs (big fishermen) and clicking on small fishermen. These clicks cannot be bridged for integrated management and are unable to realize joint management because each click fights for its interests. The function of the broker, which is expected to link structural gaps between strong groups and weak groups, does not appear on Lake Tempe. Although its potential is owned by the NGOs Tempe Rescue Forum, it has limited strategies for organizing small fishermen and limited data based on the livelihood conditions of small fishermen. It seems that NGO is trapped using technical data from the local government to support the decision to pass the management and permissive auction mechanism for several lake 
revitalization projects.

Unfortunately, this study has limitations because it does not detect the role of villages that include the Lake Tempe area, which is located on the edge of Lake Tempe as a buffer zone. The extent to which buffer villages organize the empowerment of marginalized small fishermen from the access and control of Lake Tempe. It is considering that the village now has sufficient village authority and allocation funds in the community empowerment program and the administration of BUMDes (Village Private Business Agency) according to the mandate of Law Number 6 the Year 2014 concerning Villages.

Thus, the implications of the results of this study are in accordance with the context of common natural pool resource management, which finds the fact that there is domination of state actors and local entrepreneurs in management. State actors and local entrepreneurs have high power and high interests, while small fishermen and NGOs have a high level of interest, but have a level of powerless influence. Thus, the recommended approach is the empowerment of small fishermen and NGOs to balance the role and position of the state and local entrepreneurs. When balance and equality occurs, then state actors, local entrepreneurs, small fishermen and NGOs can make partnerships as key players in the joint management of common natural pool resources belonging to Lake Tempe.

\section{References}

Baiquni, M. (2007). Strategi penghidupan di masa krisis: Belajar dari desa. Yogyakarta: IdeAs Media.

Berkes, F. (2009). Evolution of co-management: Role of knowledge generation, bridging organizations and social learning. Journal of Environmental Management, 90(5), 1692-1702. doi:10.1016/j.jenvman.2008.12.001

Berkes, F., Colding, J., \& Folke, C. (Eds.).
(2003). Navigating social-ecological systems: Building resilience for complexity and change. Cambridge: Cambridge University Press.

Berkes, F., Folke, C., \& Colding, J. (2000). Linking Social and Ecological Systems: Management Practices and Social Mechanisms for Building Resilience: Cambridge University Press.

Bodin, Ö, \& Crona, B. I. (2008). Management of Natural Resources at the Community Level: Exploring the Role of Social Capital and Leadership in a Rural Fishing Community. World Development, 36(12), 27632779. doi:10.1016/j.worlddev.2007.12.002

Bodin, Ö, \& Crona, B. I. (2008). Management of Natural Resources at the Community Level: Exploring the Role of Social Capital and Leadership in a Rural Fishing Community. World Development, 36(12), 27632779. doi:10.1016/j.worlddev.2007.12.002

Bodin, Ö, \& Crona, B. I. (2009). The role of social networks in natural resource governance: What relational patterns make a difference? Global Environmental Change, 19(3), 366-374. doi:10.1016/j. gloenvcha.2009.05.002

Bodin, Ö, Crona, B., \& Ernstson, H. (2006). Social Networks in Natural Resource Management: What Is There to Learn from a Structural Perspective? Ecology and Society, 11(2). doi:10.5751/es-01808-1102r02

Burt, R. S. (2001). Structural Holes versus Network Closure as Social Capital. Social Capital, 31-56. doi:10.4324/9781315129457-2

Carlsson, L. G., \& Sandström, A. C. (2008). Network Governance of the Commons. International Journal of the Commons, 2(1), 33. doi:10.18352/bmgnlchr.20

Carlsson, L., \& Berkes, F. (2005). Comanagement: Concepts and methodological implications. Journal of Environmental Management, 75(1), 65-76. doi:10.1016/j. jenvman.2004.11.008

Coleman, J. S., Muttaqien, I., Widowatie, D. S., \& Purwandari, S. (2008). Dasar-dasar teori 
sosial. Bandung: Nusa Media.

Crona, B., \& Bodin, Ö. (2006). What You Know is Who You Know? Communication Patterns Among Resource Users as a Prerequisite for Co-management. Ecology and Society, 11(2). doi:10.5751/es-01793-110207

Dietz, T., Ostrom, E., \& Stern, P. C. (n.d.). The Struggle to Govern the Commons. Urban Ecology, 611-622. doi:10.1007/978-0-38773412-5_40

Hamidi. (2005). Metode Penelitian Kualitatatif: Aplikasi Praktis Pembuatan Proposal dan Laporan Penelitian. Malang: UMM Press.

Hardin, G. (1968). The Tragedy of the Commons. Science, New Series, 162(3859), 1243-1248.

KLH. (2006). Master Plan Pemulihan Kerusakan Lingkungan Danau Tempe. Jakarta: Kementerian Lingkungan Hidup.

KLH. (2012). Laporan Status Lingkungan Hidup Indonesia (SLHI) 2012: Pilar Lingkungan Hidup Indonesia. Jakarta: Kementerian Lingkungan Hidup Indonesia.

KLH. (2014). Gerakan Penyelamatan Danau (Danau Tempe). Jakarta: Kementerian Lingkungan Hidup.

Lauber, T. B., Decker, D. J., \& Knuth, B. A. (2008). Social Networks and Community-Based Natural Resource Management. Environmental Management, 42(4), 677-687. doi:10.1007/s00267-0089181-8

Margono, S. A., Suharyanto, Krisnajaya, I. M. K., Subarsono, A., Sunaryo, B. (2013). Fenomena Pengelolaan "Publicness" melalui
Organisasi Non-Publik. Yogyakarta: Gava Media.

Mitchell, B., Rahmi, D. H., \& Setiawan, B. (2010). Pengelolaan sumberdaya dan lingkungan. Bulaksumur, Yogyakarta: Gadjah Mada University Press.

Ostrom, E. (1990). Governing the commons: The evolutions of institutions for collective action. Cambridge: Cambridge University Press.

Ostrom, E., Gardner, R., \&Walker, J. (1994). Rules, games, and common-pool resources. Ann Arbor: University of Michigan Press.

Prell, C., Hubacek, K., \& Reed, M. (2009). Stakeholder Analysis and Social Network Analysis in Natural Resource Management. Society \& Natural Resources, 22(6), 501-518. doi:10.1080/08941920802199202

Ritzer, G. \& Goodman, D., J. (2010). Teori Sosiologi. Yogyakarta: Kreasi Wacana.

Setiadi, Sulistyo, Satiti, S. \& Yuliono, A. (2016). Mengikis Elite Capture dalam Community Development: Pembelajaran dari Bumi Seribu Nyiur Melambai. Retrieved September 30, 2018, from https://cpps. ugm.ac.id/commonation/mengikis-elitecapture-dalam-community-developmentpembelajaran-dari-bumi-seribu-nyiurmelambai/

Yamaki, K. (2014). Network governance of endangered species conservation: A case study of Rebun Ladys-Slipper. Journal for Nature Conservation, 24, 83-92. doi:10.1016/j. jnc.2014.10.004

Yin, R., K. (2006). Studi Kasus (Desain dan Metode). Jakarta: PT. Raja Grafindo Persada. 